\title{
The Effects of Four-layer Compression Bandages and Hyperbaric Oxygen Treatment on Lower Extremity Venous Ulcers
}

\author{
Dört-Katı Kompresyon Bandajları ve Hiperbarik Oksijen Tedavisinin Alt Ekstremite Venöz \\ Ülserleri Üzerine Etkileri
}

\author{
Mustafa Aldemir', Bekir Selim Bagli² \\ ${ }^{1}$ Department of Cardiovascular Surgery; ${ }^{2}$ Department of Underwater and Hyperbaric Medicine, Bursa Higher Specialization Training \\ and Research Hospital, Health Sciences University, Bursa, Turkey
}

\begin{abstract}
Aim: Venous leg ulcers are the most common lower extremity ulcers. The pathophysiology of venous leg ulcers has not been fully elucidated. Venous leg ulcers may cause exudate, pain, and bad smell. Compression bandaging has been known as the most effective treatment modality for venous leg ulcers. This study aimed to evaluate the effects of four-layer compression bandages and hyperbaric oxygen treatment on the outcomes of patients with venous leg ulcers.
\end{abstract}

Material and Method: In our outpatient clinic of the Underwater and Hyperbaric Medicine Department between September 2016 and September 2019, 25 patients treated with four-layer compression bandages and hyperbaric oxygen adjuvant $\mathrm{HBO}$-when needed for venous leg ulcers were evaluated retrospectively for the effects on outcomes.

Results: The mean age of the patients was 57.4 years. The most common concomitant systemic disease was essential hypertension. On admission, the mean ulcer size was $74.4 \mathrm{~cm}^{2}$ and the mean ulcer duration was 20.3 months. Complete healing was achieved in all patients with a mean follow-up of 3.36 months.

Conclusion: In this study, healing rates were $64 \%$ and $92 \%$ after 12 and 24 weeks, respectively. In particular, the high healing rate achieved after 6 months proved that the treatment methods applied were reliable and effective. Using hyperbaric oxygen therapy as an adjunctive treatment method may have an impact on achieving these results. It is warranted to design further studies investigating the effect of adjunctive hyperbaric oxygen therapy on venous leg ulcers in a higher number of patients.

Key words: venous leg ulcers; hyperbaric oxygen; compression bandages
ÖZET

Amaç: Venöz bacak ülserleri alt ekstremitenin en sık görülen ülserleridir. Venöz bacak ülserlerinin patofizyolojileri tam olarak aydınlatılabilmiș değildir. Venöz bacak ülserleri sıklıkla eksuda, ağrı ve kötü koku gibi bulgulara sebep olur. Kompresyon bandajları venöz bacak ülserlerinde en etkin tedavi modalitesi olarak bilinmektedir. Biz bu çalıșma ile dört-katı kompresyon bandajları ve hiperbarik oksijen tedavisinin venöz bacak ülserleri üzerine etkilerini değerlendirmeyi amaçladık.

Materyal ve Metot: Bu çalıșmada, su altı ve hiperbarik tıp polikliniğimize Eylül 2016 ve Eylül 2019 yılları arasında venöz bacak ülseri nedeniyle bașvurmuș ve dört-katı kompresyon bandajı ile gerektiğinde adjuvan hiperbarik oksijen tedavisi de almıș 25 hasta, tedavinin etkinliğini araștırmak amacıyla retrospektif olarak incelendi.

Bulgular: Hastaların ortalama yașı 57,4 idi. Hastalardaki en sık tespit edilen sistemik kronik hastalık hipertansiyon idi. Hastaların kliniğimize bașvurduklarındaki ortalama ülser yüzey alanları 74,4 $\mathrm{cm}^{2}$ ve yine ilk ülser tanısı üzerinden geçen süre ortalama 20,3 ay idi. Çalıșmamızda incelediğimiz hastaların tamamının ortalama 3,36 aylık bir takipte tam olarak iyileștiklerini gözlemledik.

Sonuç: Bizim çalıșmamızda hastaların iyileșme oranları 12 hafta sonunda \%64 ve 24 hafta sonunda ise \%92 idi. Özellikle 6 ay sonundaki yüksek iyileșme oranı uygulanan tedavi metodlarımızın gerçekçi ve etkili olduğunu desteklemektedir. Adjuvan hiperbarik oksijen tedavisinin kullanılmıș olması bu yüksek iyileșme oranının elde edilmesindeki önemli bir faktör olabilir. Tabi ki, yüksek hasta sayıları ile planlanan çalıșmalarda ajuvan hiperbarik oksijen tedavisinin etkinliğinin araștırılmasının venöz bacak ülser tedavisine katkı sağlayacağını düșünmekteyiz.

Anahtar kelimeler: venöz bacak ülserleri; hiperbarik oksijen; kompresyon bandajları

Iletișim/Contact: Mustafa Aldemir, Mimar Sinan Mah. Emniyet Cad. No:35 Polis Okulu Karsisi 16310 Yildirim, Bursa • Tel: 05393549149 • E-mail: draldemir@yahoo.com • Geliș/Received: 18.07.2020 • Kabul/Accepted: 16.09.2020

ORCID: Mustafa Aldemir, 0000-0001-7048-5590 • Bekir Selim Bağl, 0000-0002-0942-2619 


\section{Introduction}

Venous leg ulcers (VLUs) are the most common lower extremity ulcers and account for $>70 \%$ of all ulcerations, including arterial, neuropathic and diabetic ulcers ${ }^{1}$. VLUs ocur in 1-2\% of adults in western societies. The pathophysiology of VLUs has not been fully elucidated. But, ambulatory venous hypertension has long been accepted as the principal and sole factor underlying the development of venous ulcers of the $\mathrm{leg}^{2}$. Chronic venous insufficiency (CVI) and associated venous hypertension are considered as the primary mechanisms for the formation of VLUs. Older age, obesity, diabetes mellitus, hypertension, congestive heart failure and smoking are known risk factors for the formation of VLUs ${ }^{3,4}$.

VLUs are often localized in the 1/3 distal part of the calf, the so-called gaiter region, and usually around the medial malleolus. This area is where the lower extremity is exposed to the highest hydrostatic pressure. VLUs usually remain superficial. They may cause exudate, pain, fibrin formation and bad smell 5 .

Noninvasive methods such as compression bandages and patient education are primarily preferred in the treatment of VLUs. Compression bandages have been known as the most effective treatment for VLUs ${ }^{5,6}$. Hyperbaric Oxygen (HBO) therapy is also considered as an adjunctive therapy. So far $\mathrm{HBO}$ therapy for VUs has been limited. In this report we discuss 25 patients with VLUs treated using compression bandages. Some of the patients also received HBO therapy. The aim of this study was to assess the effect of bandaging and $\mathrm{HBO}$ therapy on VLU healing as bandage and added adjuvant $\mathrm{HBO}$-when needed.

\section{Materials and Methods}

This report is a retrospective analysis of 25 patients who had been planned for treatment of their nonhealing VLUs between September 2016 and September 2019 in our outpatient clinic of the Underwater and Hyperbaric Medicine Department. We reached a total of 38 patients for that period. They had been planned for treatment of VLUs verified as venous insufficiency on duplex imaging. Thirteen of these patients who had discontinued the treatment plan were excluded from analysis. Thus, 25 patients were evaluated in this study. They were evaluated with respect to demographic features, concomitant diseases, ulcer size and duration, treatment details and outcomes.
Four-layer compression bandages (Parris, Istanbul Medikal, Istanbul, Türkiye) were applied to all patients as the main treatment method twice weekly until the ulcer healed ${ }^{6,11,15}$. Compression bandaging was carried out by a trained nurse under the supervision of a physician. Bandages were discarded after each use. Bandage soiling and bad smell was thought to be prevented with this application frequency for large and exudative ulcers. All participants were encouraged to exercise and elevate the affected leg as much as possible. None of these patients underwent any surgical intervention during follow-up.

HBOT was applied to patients who did not show any signs of improvement with 4 weeks of four-layer compression bandaging. Each patient who was given HBO therapy was informed about HBOT issues, and informed consent was obtained. HBOT was administered in a multiplace chamber at 2.4 ATA, one session per day, 5 days a week. Each session of HBOT lasted about 120 minutes including three 25-minute oxygen periods in which patients breathed $100 \%$ oxygen at 2.4 ATA, separated by 5 -minute air breaks, and compression and decompression in the remaining time.

The primary outcome of the study was healing time. If more than one ulcer had been present, the largest one was identified as the index ulcer for the study. Healing was defined as complete coverage of the ulcer by epithelial regeneration with no clinical signs of infection.

\section{Statistical Analysis}

Data were analyzed using SPSS 21.0 software. Continuous variables were expressed as mean \pm standard deviation (SD) and categorical variables were expressed as $\mathrm{n}(\%)$. Differences in means between the $\mathrm{HBO}$ therapy group and the non-HBO therapy group were analyzed by Mann-Whitney U test. The relationship between age, body mass index (BMI), CVI duration, ulcer size, ulcer duration and healing time were analysed by Spearman's rho correlation test. $\mathrm{P}$ value $<0.05$ was considered statistically significant.

\section{Results}

Mean age of the patients was $57.4 \pm 15.2$ years $(34-82) ; 6$ (24\%) were female. Mean BMI of the patients was calculated as 33.4 (20-46). The most common concomitant systemic diseases were essential hypertension (28\%) and diabetes mellitus (24\%). Mean CVI duration of the patients was 7.9 years. 15 of the patients were smokers. 13 of the patients were reported as having recurrent VLU. Patient characteristics are presented in Table 1. 
Twelve of the patients had VLU on the right leg, seven of them had VLU on the left leg, and six of them had VLU on both legs. On admission, the mean ulcer size was $74.4(3-500) \mathrm{cm}^{2}$ and the mean ulcer duration was 20.3 (2-156) months. Ulcers of 12 patients were fibrotic on more than $50 \%$ of the wound surface.

Table 1. Characteristics of patients with venous leg ulcer

\begin{tabular}{ll}
\hline Mean age (years) & $57.48 \pm 15.20$ \\
\hline Gender female male & $6(24 \%)$ \\
& $19(76 \%)$ \\
BMI & $33.40 \pm 7.22$ \\
Systemic diseases & \\
Essential hypertension & $7(28 \%)$ \\
Diabetes mellitus & $6(24 \%)$ \\
Congestive heart failure & $3(12 \%)$ \\
CVI duration (years) & $7.96 \pm 5.20$ \\
Venous insufficiency deep superficial & $19(76 \%)$ \\
& $6(24 \%)$ \\
Smoking & $15(60 \%)$ \\
VLU history & $13(52 \%)$ \\
Evidence of previous DVT & $15(60 \%)$ \\
Deep venous reflux & $19(76 \%)$ \\
\hline
\end{tabular}

Nine patients had received 30 sessions of $\mathrm{HBO}$ therapy as an adjunctive therapy. Complete healing was achieved in all patients with a mean follow-up of 3.36 months (min: 2 weeks, max: 10 months).

Mean ulcer duration and mean ulcer size were significantly higher in the $\mathrm{HBO}$ therapy group than the nonHBO therapy group (p: 0.021 and p: 0.036 , respectively). There was no statistically significant difference between these two groups in healing time (Table 2).

There was a moderate correlation between ulcer size and healing time (correlation coefficient: 0.737; p: 0.001), whereas there was a weak correlation between CVI duration and ulcer duration (correlation coefficient: $0.420 ; \mathrm{p}: 0.037)$. No significant correlation was detected among other variables.

\section{Discussion}

VLU pathophysiology is still not fully elucidated. Some ulcers heal slower and tend to relapse and this cannot be estimated initially. Compression bandages are the main therapy for VLUs $s^{6}$. There are some publications reporting that $\mathrm{HBO}$ therapy can also be effective ${ }^{7,8}$.

The age and gender profile in this study showed that males under 65 years old were predominant. Although

Table 2. Ulcer properties

\begin{tabular}{|c|c|c|c|c|c|}
\hline & \multirow[t]{2}{*}{ mean $\pm S D$} & \multicolumn{3}{|c|}{ n (\%) } & \multirow[t]{2}{*}{$\mathrm{p}$} \\
\hline & & Total & $\mathrm{HBO}$ & non-HBO & \\
\hline \multicolumn{6}{|l|}{ Ulcerated leg } \\
\hline Right & & $12(48 \%)$ & $3(33 \%)$ & $9(56 \%)$ & \\
\hline Left & & $7(28 \%)$ & $2(22 \%)$ & $5(31 \%)$ & \\
\hline Both & & $6(24 \%)$ & $4(44 \%)$ & $2(13 \%)$ & \\
\hline \multicolumn{6}{|l|}{ Ulcer localization } \\
\hline Lower inner \& front calf & & $3(12 \%)$ & $1(11 \%)$ & $2(13 \%)$ & \\
\hline Lower anterior calf & & $2(8 \%)$ & $1(11 \%)$ & $1(6 \%)$ & \\
\hline Lower lateral calf & & $4(16 \%)$ & $1(11 \%)$ & $3(18 \%)$ & \\
\hline Lower medial calf & & $16(64 \%)$ & $6(66 \%)$ & $10(62 \%)$ & \\
\hline Fibrin (>50\%) & & $12(48 \%)$ & $4(44 \%)$ & $8(50 \%)$ & \\
\hline Ulcer duration (months) & $20.32 \pm 37.16$ & & & & 0.021 \\
\hline$<6$ months & & $12(48 \%)$ & $3(33 \%)$ & $9(56 \%)$ & \\
\hline $6-12$ months & & $8(32 \%)$ & $2(22 \%)$ & $6(38 \%)$ & \\
\hline$>12$ months & & $5(20 \%)$ & $4(44 \%)$ & $1(6 \%)$ & \\
\hline Ulcer size $\left(\mathrm{cm}^{2}\right)$ & $74.44 \pm 111.41$ & & & & 0.036 \\
\hline$<50 \mathrm{~cm}^{2}$ & & $15(60 \%)$ & $4(44 \%)$ & $11(69 \%)$ & \\
\hline $51-100 \mathrm{~cm}^{2}$ & & $4(16 \%)$ & $3(33 \%)$ & $1(6 \%)$ & \\
\hline$>100 \mathrm{~cm}^{2}$ & & $6(24 \%)$ & $2(22 \%)$ & $4(25 \%)$ & \\
\hline Healing time (months) & $3.36 \pm 2.51$ & & & & 0.141 \\
\hline$<3$ months & & $16(64 \%)$ & $5(56 \%)$ & $11(69 \%)$ & \\
\hline $3-6$ months & & $7(28 \%)$ & $2(22 \%)$ & $5(31 \%)$ & \\
\hline$>6$ months & & $2(8 \%)$ & $2(22 \%)$ & $0(0 \%)$ & \\
\hline
\end{tabular}


some studies have underlined that patients are mainly of advanced age and female ${ }^{9,13}$, there are also other studies showing the opposite ${ }^{5}$. Age and gender characteristics of the patients should bring to mind different etiologies. For example, patients younger than expected may bring to mind congenital etiologies.

In this study, nine of the patients were morbid obese $(\mathrm{BMI}>35)$ and eight of the patients were obese (BMI $>30$ ). In the study published by Kelly et al, BMI was considered as one of the situations delaying VLU recovery $^{3}$. In our study, high BMI may have been one of the reasons for a relatively longer healing time (3.36 months) $)^{13}$.

Hypertension is a risk factor for CVI. Seven (28\%) of the patients in this study had essential hypertension. Kelly et al. found essential hypertension in $60 \%$ of their CVI patients. ${ }^{3}$. Why our rate was lower can be explained by the fact that our patients were relatively young.

In this study, the mean CVI duration was similar to other studies in the literature ${ }^{3}$. A weak correlation between CVI duration and ulcer duration seems logical in the first instance, but it may be incidental for VLUs progressing with frequent relapses.

VLUs are generally localized in the gaiter region, between the malleolus and calf muscle ${ }^{4}$. Similarly, in this study, $76 \%$ of the patients had VLUs originating from the lower inner calf region.

In this study, the larger ulcer size and longer ulcer duration time can be argued as evidence for more difficult cases being admitted to our clinic. The moderate correlation between ulcer size and healing time and these being higher than previous studies support this opinion ${ }^{13}$.

Margolis et al. ${ }^{9}$ stated that the presence of fibrin in more than $50 \%$ of the wound surface is associated with inability to heal venous ulcers. Similarly, Milic et al. ${ }^{11}$ have stated that the presence of fibrin on more than $50 \%$ of the wound surface is an indicator of slow healing. In this study, the relationship between the presence of fibrin on more than $50 \%$ of the wound surface and the healing time could not be analysed due to the small sample size.

In a study conducted by Harrison et al. ${ }^{14}$, the healing rates after three and six months were $58 \%$ and $69 \%$, respectively. In this study, these rates were $64 \%$ and $92 \%$, respectively. In our study, the higher healing rate achieved after 6 months may prove that $\mathrm{HBO}$ as an adjunctive treatment is reliable and effective.
Local tissue hypoxia as an unfavorable environment is considered one of the reasons for a prolonged inflammation phase with chronic wounds. During hyperbaric oxygen therapy, patients breath $100 \%$ oxygen intermittently in a closed chamber at pressures of 1-3 atmospheres absolute (ATA). With HBO therapy, the partial pressure of $\mathrm{O} 2$ ( $\mathrm{pO} 2$ ) increases, more oxygen can be delivered to tissues and tissue oxygen tension increases, especially in hypoxic tissues ${ }^{14}$. In this regard, $\mathrm{HBO}$ may have improved the hypoxic environment of VLUs and may have contributed to the outcome of this study.

In a randomized, double-blind, placebo-controlled study published in 2018, Thistlethwaite et al. ${ }^{8}$ concluded that HBOT is an effective adjunctive therapy when used in selected patients with VLUs resistant to compression bandage treatment alone. In our study, larger ulcer size $\left(111.1 \mathrm{~cm}^{2}\right.$ versus $53.8 \mathrm{~cm}^{2}$; p: 0.036$)$ and longer ulcer duration (42.2 months versus 8.0 months; p: 0.021) in the HBO group may confirm our relevant patient selection for $\mathrm{HBO}$ therapy.

All patients healed completely after a mean follow-up of 3.36 months. There was also a moderate correlation between ulcer size and healing time. The use of $\mathrm{HBO}$ therapy as an adjunctive method should be kept in mind for large VLUs unresponsive to compression treatment alone after 4 weeks.

It is warranted to investigate risk factors of VLUs in more detail and to evaluate them with outcomes in a higher number of patients with application of four-layer compression bandages and HBO therapy together. A good understanding of the factors affecting outcomes can be a guide for the selection of more effective and faster therapies.

\section{References}

1. Abbade LP, Lastória S. Venous ulcer: epidemiology, physiopathology, diagnosis and treatment. Int J Dermatol 2005;44(6):449-56. Review. PubMed PMID:15941430.

2. Mansilha A, Sousa J. Pathophysiological Mechanisms of Chronic Venous Disease and Implications for Venoactive Drug Therapy. Int J Mol Sci 2018;19(6):1669.

3. Abbade LP, Lastória S, Rollo Hde A. Venous ulcer: clinical characteristics and risk factors. Int J Dermatol 2011;50(4):405-11.

4. Kelly M, Gethin G. Prevalence of Chronic Illness and Risk Factors for Chronic Illness Among Patients With Venous Leg Ulceration: A Cross-Sectional Study. Int J Low Extrem Wounds 2019;18(3):301-308. 
5. Kelechi TJ, Johnson JJ, Yates S. Chronic venous disease and venous leg ulcers: An evidence-based update. J Vasc Nurs 2015;33(2):36-46.

6. Kuplay H, Özkaynak B, Mert B, Erdoğan S, Sönmez S, Kayalar N, et al. Kronik Venöz Yetmezliğe Bağlı Venöz Bacak Ülserlerinde Çok Katlı Kompresyon Bandaj Sistemlerinin Etkisi. Koşuyolu Kalp Dergisi 2012;16(1):54-57.

7. Neumann HA. Evidence-based (S3)guidelines for diagnostics and treatment of venous leg ulcers. J Eur Acad Dermatol Venereol 2016;30(11):1843-1875.

8. Hammarlund C, Sundberg T. Hyperbaric oxygen reduced size of chronic leg ulcers: a randomized double-blind study. Plast Reconstr Surg 1994;93(4):829-33; discussion 834.

9. Thistlethwaite KR, Finlayson KJ, Cooper PD, Brown B, Bennett $\mathrm{MH}$, Kay G, et al. The effectiveness of hyperbaric oxygen therapy for healing chronic venous leg ulcers: A randomized, double-blind, placebo-controlled trial. Wound Repair Regen 2018;26(4):324-331.

10. Barwell JR, Davies CE, Deacon J, Harvey K, Minor J, Sassano A, et al. Comparison of surgery and compression with compression alone in chronic venous ulceration (ESCHARstudy): randomised controlled trial. Lancet 2004;363(9424):1854-1859.
11. Margolis DJ, Berlin JA, Strom BL. Risk factors associated with the failure of a venous leg ulcer to heal. Arch Dermatol 1999;135(8):920-6.

12. Milic DJ, Zivic SS, Bogdanovic DC, Karanovic ND, Golubovic $\mathrm{ZV}$. Risk factors related to the failure of venous leg ulcers to heal with compression treatment. J Vasc Surg 2009;49(5):1242-7.

13. Phillips TJ, Machado F, Trout R, Porter J, Olin J, Falanga V. Prognostic indicators in venous ulcers. J Am Acad Dermatol 2000;43(4):627-30.

14. Harrison MB, Vandenkerkhof EG, Hopman WM, Graham ID, Carley ME, Nelson EA. Canadian Bandaging Trial Group. The Canadian Bandaging Trial: Evidence-informed leg ulcer care and the effectiveness of two compression technologies. BMC Nurs 2011;10:20.

15. Löndahl M, Katzman P, Nilsson A, Hammarlund C. Hyperbaric oxygen therapy facilitates healing of chronic foot ulcers in patients with diabetes. Diabetes Care 2010;33(5):998-1003.

16. Scriven JM, Taylor LE, Wood AJ, Bell PR, Naylor AR, London NJ. A prospective randomised trial of four-layer versus short stretch compression bandages for the treatment of venous leg ulcers. Ann R Coll Surg Engl 1998;80(3):215-220. 